\title{
PREVALENSI OBESITAS PADA REMAJA SMA YPKM DI KOTA MANADO
}

\author{
${ }^{1}$ Donald Andreas Chandra \\ ${ }^{2}$ Aaltje E. Manampiring \\ ${ }^{3}$ Fatimawali
}

\author{
${ }^{1}$ Kandidat Skripsi Fakultas Kedokteran Universitas Sam Ratulangi Manado \\ ${ }^{2}$ Bagian Kimia Fakultas Kedokteran Universitas Sam Ratulangi Manado \\ Email: donaldandreaschandra@gmail.com
}

\begin{abstract}
Obesity is defined as a condition in which an abnormal accumulation of fat in adipose tissue or redundant to some extent which can be harmful to health. One of the risk factors of obesity are environmental factors, a category including behavioral or lifestyle patterns (e.g. what to eat and how many times a person eats and how their activities) are experienced by many young people in the city of Manado. The purpose of this study was to determine the prevalence of obesity in adolescents. This study used cross sectional method with descriptive approach, the sampling technique which used is simple random sampling. The research sample is 100 students who met the inclusion criteria were age 13-18 years, willing to be sampled. Data retrieval is done by measuring waist circumference, weight, and height. Based on the measurement of waist circumference in 100 populations found 10 people students were obesity with a percentage of $10 \%$ which consist of 6 boys with the percentage of $6 \%$ and 4 girls with a percentage of 4\%. Meanwhile, if measured by BMI CDC 2000 found 9 students who are obesity by $9 \%$ which consists of 6 boys with a percentage of $6 \%$ and 3 girls with a percentage of $3 \%$.

Keyword: Obesity, adolescents.
\end{abstract}

\begin{abstract}
Abstrak: Obesitas didefinisikan sebagai suatu kondisi akumulasi lemak yang tidak normal atau berlebihan di jaringan adiposa sampai kadar tertentu sehingga dapat merusak kesehatan. Salah satu faktor resiko obesitas adalah faktor lingkungan, dimana termasuk perilaku/pola gaya hidup (misalnya apa yang dimakan dan berapa kali sesesorang makan serta bagaimana aktifitasnya) yang banyak dialami oleh para remaja di Manado. Tujuan penelitian ini adalah untuk mengetahui prevalensi obesitas pada remaja. Penelitian ini menggunakan metode cross sectional dengan pendekatan dekskriptif. Teknik pengambilan sampel yang digunakan adalah dengan menggunakan cara simple random sampling. sampel penelitian sebanyak 100siswa-siswi yang memenuhi kriteria inklusi yang berusia 13-18 tahun, bersedia menjadi sampel. Pengambilan data dilakukan dengan cara pengukuran lingkar pinggang, berat badan, dan tinggi badan. Berdasarakan hasil pengukuran lingkar pinggang pada 100 populasi didapatkan 10 orang siswasiswi mengalami obesitas dengan presentase sebesar $10 \%$ yang terdiri dari 6 orang siswa dengan presentase $6 \%$ dan 4 orang siswi dengan presentase sebesar $4 \%$. Sedangkan jika diukur berdasarkan IMT CDC 2000 didapati 9 siswa-siswi yang mengalami obesitas dengan presentase sebesar 9\% yang terdiri dari 6 orang siswa dengan presentase $6 \%$ dan 3 orang siswi dengan presentase sebesar 3\%.
\end{abstract}

Kata kunci: Obesitas, Remaja

Definisi obesitas bukan lagi suatu gejala dari penyakit namun saat ini obesitas telah digolongkan menjadi suatu penyakit. $^{(1)}$ Obesitas pada remaja meningkatkan resiko penyakit kardiovaskuler pada saat dewasa karena kaitannya dengan sindroma metabolik yang terdiri dari resistensi insulin/ hiperinsulinemia, intoleransi glukosa/diabetes melitus, dislipidemia, hiperurisemia, gangguan fibrinolisis, dan hipertensi. ${ }^{(2)}$ 
Prevalensi obesitas meningkat dua kali lipat dalam dekade terakhir dan sekarang mencapai $15 \%$ dari populasi dewasa di inggris dan $50 \%$ pada ras tertentu. ${ }^{(3)}$ Penelitian perseorangan telah menggambarkan prevalensi obesitas pada masa kanakkanak sebesar 7-43\% di Kanada, 7,3\% pada umur 6-11 tahun di Inggris, dan 21,9\% pada umur 12-17 tahun di Amerika serikat. ${ }^{(4)}$

Di negara berkembang, jumlah anak sekolah dengan overweight paling banyak berada di kawasan Asia yaitu $60 \%$ populasi atau sekitar 10,6 juta jiwa ${ }^{(5)}$. Penelitian tersebut melibatkan 227 ribu remaja Norwegia antara usia 14 - 19 tahun, yang diukur tinggi dan berat badannya antara tahun 1963-1975. Dengan mengikuti perkembangan mereka sampai tahun 2004, di mana rata-rata dari responden telah berusia 52 tahun, ditemukan sebanyak 9650 orang di antaranya meninggal karena obesitas. ${ }^{(6)}$ Pada penelitian di kota Tomohon dan Tondano pada tahun 2010 masingmasing kota memiliki prevalensi obesitas yang tinggi pada usia remaja. Kota Tomohon memiliki remaja dengan prevalensi obesitas sekitar $35 \%$. Sementara kota Tondano memiliki remaja dengan prevalensi obesitas sekitar 38,2\%. ${ }^{(7,8)}$ Hasil Riset Kesehatan Dasar (Riskesdas) Indonesia pada tahun 2010 yang dikeluarkan oleh Kementerian Kesehatan menyatakan prevalensi obesitas pada perempuan tertinggi berada di daerah Sulawesi Utara, Kepulauan Bangka Belitung, dan Gorontalo. Daerah Sulawesi Utara memiliki prevalensi obesitas sekitar 29,5\%, Bangka Belitung sekitar 22,8\% dan Gorontalo sekitar $22,1 \%{ }^{(9)}$. Prevalensi remaja yang mengalami kelebihan berat badan dan obesitas berdasarkan data Riset Kesehatan Dasar (RISKESDAS) tahun 2007 dan 2010.

Sebagai tambahan informasi, Riskesdas 2007 menggunakan standar Indeks Massa Tubuh (IMT), sedangkan Riskesdas 2010 menggunakan IMT/ Umur berdasaran rujukan WHO 2005. Disamping itu, Riskesdas 2010 tidak memunculkan data kelebihan berat badan pada remaja. ${ }^{\text {(9) }}$ Secara umum obesitas dapat digolongkan ke dalam tiga tingkatan, yaitu: a) obesitas ringan yaitu kelebihan berat badan 20 s/d 40\%; b) obesitas sedang yaitu kelebihan berat badan 41 s/d 100\%; c) obesitas berat yaitu kelebihan berat badan lebih besar dari $100 \%{ }^{(10)}$

Distribusi lemak dapat meningkatkan risiko yang berhubungan dengan berbagai macam penyakit degeneratif. Seseorang yang memiliki berat badan 20\% lebih tinggi dari nilai tengah kisaran berat badannya yang normal dianggap mengalami obesitas $^{(10,11)}$ Tipe Obesitas berdasarkan bentuk tubuh yaitu Obesitas tipe buah apel (apple shape), tipe buah pear (gynoid), dan tipe kotak (ovid). Tipe buah apel (apple shape) biasa di alami oleh pria di mana lemak terpusat pada daerah di sekitar perut. Obesitas tipe buah pear (gynoid) cenderung di alami oleh wanita dimana lemak terpusat pada daerah sekitar pinggul dan bokong. Obesitas tipe kotak (ovid) merupakan obesitas dimana lemak terpusat pada seluruh bagian tubuh, yang biasanya juga terjadi pada obesitas secara genetik. ${ }^{(10,12)}$

Index massa tubuh (IMT) merupakan angka yang menunjukan apabila seseorang terlalu berat untuk tinggi badan mereka. Selain itu IMT juga dapat digunakan untuk menentukan seberapa besar seseorang dapat menglami resiko penyakit tertentu yang terkait dengan berat badan. ${ }^{(13)}$ Berikut ini merupakan klasifikasi IMT menurut WHO (1998). ${ }^{(13)}$

Dari Tabel 1 dapat diketahui bahwa: a) seseorang berada di kisaran berat badan normal jika IMT antara 18,5 -25 ( $\left.\mathrm{Kg} / \mathrm{m}^{2}\right)$; b) seseorang kelebihan berat badan atau gemuk jika IMT antara 25-30 $\left(\mathrm{Kg} / \mathrm{m}^{2}\right)$; c) seseorang mengalami obesitas jika IMT 30 atau lebih; d) seseorang mengalami obesitas berbahaya jika IMT 35 atau lebih tinggi.

Di Indonesia ditemukan prevalensi obesitas sebesar 9,7\% di Yogyakarta, 10,6 \% di Semarang dan 15,8\% di Denpasar. Pada tahun 1989 prevalensi obesitas pada daerah perkotaan di Indonesia adalah 4,6\% pada anak laki-laki dan 5,9 \% pada anak perempuan. Empat tahun kemudian naik menjadi 6,3\% pada anak laki-laki dan $8 \%$ pada anak perempuan. ${ }^{(14)}$

Menurut Nurmalina (2011) beberapa orang mengalami kenaikan berat badan 
Chandra, Manampiring, Fatimawali; Prevalensi Obesitas Pada Remaja...

ketika mereka berhenti merokok. Salah satu alasannya adalah selera makan menjadi naik setelah berhenti merokok. ${ }^{(15)}$

Tabel 1. Klasifikasi IMT menurut WHO

\begin{tabular}{|c|c|c|}
\hline Kategori & $\underset{\left(\mathbf{k g} / \mathbf{m}^{2}\right)}{\mathrm{IMT}}$ & $\begin{array}{c}\text { Risiko } \\
\text { komorbiditas }\end{array}$ \\
\hline $\begin{array}{l}\text { Underweight } \\
\text { (kekurangan } \\
\text { berat badan) }\end{array}$ & $\begin{array}{l}<18.5 \\
\mathrm{~kg} / \mathrm{m}^{2}\end{array}$ & $\begin{array}{c}\text { Rendah, tetapi } \\
\text { risiko terhadap } \\
\text { masalah- } \\
\text { masalah klinis } \\
\text { lain meningkat }\end{array}$ \\
\hline Normal & $\begin{array}{c}18.5-24.9 \\
\mathrm{~kg} / \mathrm{m}^{2}\end{array}$ & Rata-rata \\
\hline $\begin{array}{l}\text { Overweight } \\
\text { (kelebihan } \\
\text { berat badan) }\end{array}$ & $\begin{array}{c}25.0-29.9 \\
\mathrm{~kg} / \mathrm{m}^{2}\end{array}$ & Normal tinggi \\
\hline $\begin{array}{l}\text { Obese } 1 \\
\text { (obesitas 1) }\end{array}$ & $\begin{array}{c}30.0-34.9 \\
\mathrm{~kg} / \mathrm{m}^{2}\end{array}$ & Obesitas sedang \\
\hline $\begin{array}{l}\text { Obese } 2 \\
\text { (obesitas 2) }\end{array}$ & $\begin{array}{c}35.0-39.9 \\
\mathrm{~kg} / \mathrm{m}^{2}\end{array}$ & $\begin{array}{c}\text { Obesitas } \\
\text { berbahaya }\end{array}$ \\
\hline $\begin{array}{l}\text { Obese } 3 \\
\text { (obesitas 3) }\end{array}$ & $\begin{array}{l}>40.0 \\
\mathrm{~kg} / \mathrm{m}^{2}\end{array}$ & $\begin{array}{c}\text { Obesitas sangat } \\
\text { berbahaya }\end{array}$ \\
\hline
\end{tabular}

Menurut Nurmalina (2011) kurangnya area pejalan kaki dan tempat yang aman untuk rekreasi di lingkungan sekitar menyebabkan kurangnya aktivitas secara fisik pada seseorang. Seseorang dengan lemak tubuh yang terlalu banyak dapat mengalami beberapa gejala berikut: a) depresi atau gangguan emosional; b) kesulitan bergerak; c) sakit punggung dan lutut; d) sesak napas; e) ruam pada kulit; f) mendengkur; g) komplikasi medis. ${ }^{(15)}$

Pada sebagian besar penderita obesitas terjadi resistensi leptin, sehingga tingginya kadar leptin tidak menyebabkan penurunan nafsu makan. ${ }^{(16)}$ Penelitian lain juga menyatakan bahwa kegemukan dapat diturunkan, sehingga memungkinkan orang tua yang gemuk memiliki anak yang gemuk juga. Hal ini melibatkan banyak faktor genetik serta proses pengeluaran dan pemasukan energi. ${ }^{(17)}$

\section{METODE PENELITIAN}

Penelitian ini bersifat cross sectional dengan pendekatan deskriptif.Pengambilan sampel dilakukan di sekolah SMA YPKM Manado.Pengambilan sampel dilakukan di sekolah SMA YPKM Manado.Penelitian ini akan mengambil sampel siswa SMA YPKM di kota Manado yang berusia 13-18 tahun. Dengan teknik pengambilan sampel secara simple random sampling.

\section{HASIL PENELITIAN}

Tabel 2. Prevalensi Obesitas berdasarkan Lingkar Pinggang

\begin{tabular}{cccc}
\multirow{2}{*}{ Jenis } & \multicolumn{2}{c}{ Obese } & \\
\cline { 2 - 3 } Kelamin & $\begin{array}{c}\text { Obesitas } \\
\text { Ya }\end{array}$ & $\begin{array}{c}\text { Obesitas } \\
\text { Tidak }\end{array}$ & Total \\
\hline $\begin{array}{c}\text { Laki-laki } \\
\text { Lingkar }\end{array}$ & & & \\
$\begin{array}{c}\text { Pinggang } \\
\quad>90\end{array}$ & 6 & 54 & 60 \\
$\begin{array}{c}\text { Perempuan } \\
\text { Lingkar }\end{array}$ & 4 & 36 & 40 \\
$\begin{array}{c}\text { Pinggang } \\
\quad>80\end{array}$ & 10 & 90 & 100 \\
Total & & & \\
\hline
\end{tabular}

Dari Tabel di atas terlihat bahwa dari 100 siswa yang diukur lingkar pinggang, berat badan, dan tinggi badan, terdapat 10 siswa yang termasuk dalam kriteria obesitas adalah 10 siswa yang terdiri dari 6 siswa laki-laki dan 4 siswa perempuan.

Tabel 3. Prevalensi Obesitas berdasarkan IMT (CDC 2000) :

\begin{tabular}{llll}
\hline \multirow{2}{*}{$\begin{array}{l}\text { Jenis } \\
\text { Kelamin }\end{array}$} & Obese & \multicolumn{2}{c}{ Total } \\
\cline { 2 - 3 } & $\begin{array}{l}\text { Obesitas } \\
\text { Ya }\end{array}$ & $\begin{array}{l}\text { Obesitas } \\
\text { Tidak }\end{array}$ & \\
\hline \multirow{2}{*}{ Laki-Laki } & 6 & 54 & 60 \\
Perempuan & 3 & 37 & 40 \\
Total & 9 & 91 & 100 \\
\hline
\end{tabular}


Dari Tabel 3 di atas menurut IMT ( CDC 2000 ) terlihat bahwa dari 100 siswa terdapat 9 siswa obesitas yaitu 6 siswa lakilaki dan 3 siswa perempuan.

\section{DAFTAR PUSTAKA}

1. Anonimous. Obesitas Pada Remaja. http://www.scribd.com. Akses: 8 November 2012

2. Sidartawan S. Perjalanan Obesitas menuju Diabetes Melitus dan Penyakit Kardiovaskuler. Jakarta: FKUI.p. 1-23

3. Davey P. At a Glance Medicine. In: Rahmalia A, Novianty C, Safitri A, Editors. Jakarta: Erlangga; 2005.p.54.

4. Wahab AS. Ilmu Kesehatan Anak Nelson. Ed. 15. Jakarta: EGC; 1999.p.216

5. Sani, Asrul. 2010. Obesitas dan Penanganannya. www.dokterasrul.com. Akses: 8 November 2012

6. Ajibarang. 2008. Atasi segera Obesitas Pada Remaja. http://www.keperawatangun.blogspot.com. Akses: 8 November 2012

7. Dangin, Ni Nengah I. A. 2010. Prevalensi Sindroma Metabolik Pada Remaja di Kota Tomohon.

8. Lambiombir, Liciana. 2010. Skripsi Prevalensi Hiperurisemia Pada Remaja Obesitas di kota Tondano

9. Anonimous 2010. Riset kesehatan Dasar Riskesdas 2010 Badan Penelitian dan Pengembangan Kesehatan. Kementrian
Kesehatan RI 2010. http://riskesdas.litbang.depkes.go.id/2010/.

Akses: 11 Desember 2012

10. Obesitas. Diunduh dari: id.wikipedia.org/wiki/Obesitas. Akses: 28 Oktober 2012

11. Overweight \& Obesitas sebagai suatu Resiko Penyakit Degeneratif. Diunduh dari: http://fai-kao.com/2011. Akses: 28 Oktober 2012.

12. Obesitas. Diunduh dari: http://id.scribd.com. Akses: 8 November 2012

13. Sugondo S. Obesitas. Dalam Buku Ajar Ilmu Penyakit Dalam. Jilid III Edisi ke-5. Jakarta: Departemen Ilmu Penyakit Dalam Fakultas Kedokteran Universitas Indonesia; 2009. Hal 1973-83.

14. Adityawarman. 2007. Hubungan Aktivitas Fisik dengan Komposisi Tubuh pada Remaja. http://eprints.undip.ac.id/22215/1/Aditya.pd f. Akses 28 Oktober 2012

15. Nurmalina, R. 2002. Pencegahan dan Manajemen Obesitas. Jakarta: PT. Elex Media Komputindo.

16. Anonimous. Patofisiologi Obesitas. Diunduh dari: http://id.scribd.com/doc/68130545/PATOFI SIOLOGI-OBESITAS. Akses: 7 Oktober 2012

17. IMT Obesitas. Diunduh dari: http://obesitas.web.id. Akses: 7 Oktober 2012 